\title{
Evolution of Dual Containment Policy (the Policy of Clinton's Administration - Clinton's Doctrine) in the Persian Gulf
}

\author{
Seyed Mohsen Mirhosseini \\ Yazd University, Iran \\ *Corresponding Author: mmirhosaini@yazd.ac.ir
}

Copyright (c) 2014 Horizon Research Publishing All rights reserved.

\begin{abstract}
During 1993-1997, the policy of dual containment was selected by Clinton's administration to prevent Iran and Iraq from any action jeopardizing the interests of the international community especially the United State of America. The new policy of dual containment was the result of the new world order in which the U.S. found itself as the hub of the new world after the collapse of the Soviet Union. Also, this new policy put away the balance of power policy that was the main policy of previous American administrations which had sought a balance of power between Iran and Iraq in order to contain these two nations from any aggression to the global peace and security.
\end{abstract}

Keywords Dual Containment, Persian Gulf, Clinton's Policy, Balance of power

\section{Background}

The background of the Dual containment policy goes back to 1991 when the US seriously assumed responsibility for the Persian Gulf security and arranged the GCC states dependence on the US and West for security and decided to contain two main Persian Gulf powers, the Islamic Republic of Iran and Iraq. Some incidents intensified the dual containment policy: 1) the Iranian description of the U.S. as the "Great Satan" had its effects in the media, in congress, and on the public and in the attitude of lower-level bureaucrats; 2) the terrorist bombing of the U.S. military camp at Dhahran, Saudi Arabia in 1996 that killed 19 American servicemen and raised concerns that Iran was behind the attack (Gary Sick, p. 66).

During the Dual Containment strategy, there were several preventive actions against the Islamic Republic of Iran such

\footnotetext{
1 "Great Satan" was a cognomen that the ex leader of Iran -Ayatollah Khomeini- named the US.
}

as sanctions, embargoes, and limitation on transfer of sensitive technologies to Iran and Iraq. The main sanctions were on the oil and gas industry in Iran. For example, the U.S. congress prepared a bill that would impose sanctions on any foreign corporation that invested 40USD million or more in the Iranian oil and gas industry (after one year reduced to USD20 million). The bill was known as the Iran-Libya Sanction Act (ILSA) because Libya was later added by the senate (Alikhani, 2000).

During the Dual Containment period, the kingdom of Saudi Arabia and the sheikhdom of Kuwait were mainly worried about the conventional threat from Iraq and saw Iran as a counterbalance to the Iraqi regime (Katzman, 2006). Other lower states of the Persian Gulf region such as the $\mathrm{UAE}^{2}$, Qatar, and Bahrain tended to view Iran as a greater danger than Iraq.

In 1969 when containment was effective at causing the collapse of the Soviet Union, Kissinger described containment as the expense of the US ability to "contribute to building a stable and creative world order." However, twenty five years later, Kissinger described the containment policy as a "doctrine of perpetual struggle" based on "the age-old American dream of a peace achieved by the conversion of the adversary" (Kissinger, 1994). The US victorious containment policy during the Cold War had a clear mandate for continued US primacy, established in the 20th century that also involves the Dual Containment policy. The invasion of Kuwait by Iraq in 1990 threatened US strategic interests in the Middle East and Persian Gulf, so it was determined after the Persian Gulf War that a long time US military presence would be required in the Persian Gulf region to serve as deterrent for what the Clinton administration called "rouge states". During the 1990s, the term "rogue states" would come to describe those states with an apparent disregard for international treaties and norms, and a desire to develop, acquire, or distribute Weapons of Mass Destruction (Litwak, 2002).

The administration position of the United States toward

\footnotetext{
${ }^{2}$ United Arab Emirates
} 
Iran and Iraq, before declaration of the Dual Containment policy, was indicated by Anthony Lake, the assistant to President Clinton for national security affairs. Lake has stated that US policy must face the reality of unruly states that chose to remain outside the family of nations. These nations, which Anthony Lake labeled as "backlash states" were Cuba, North Korea, Libya, Iran and Iraq. Anthony Lake, with acknowledgements to George Kennan, predicted that after having successfully contained Soviet power, the US "... as sole superpower ... now faces a less formidable challenge in containing the band of outlaws" (Lake, 1994a, pp. 60-62). Defending Dual Containment, Lake claimed that it was a "realistic and sustainable policy", though he recognized the risk that Iran and Iraq "may be driven together in their efforts to resist the West" and that Iran may be inclined to "meddle and prey on Iraqi weakness (Lake, 1994a, pp. 45-46,55). Lake suggested three methods for containing the influence of these states: 1) isolation 2) pressure ,and 3) diplomatic and economic measures (Lake, 1994a, pp. 45-46,55).

\section{Basic codes of the dual containment policy}

The basic roles of the Dual Containment policy were outlined by Martin Indyk, the Special Assistant to the President for Near East and South Asian affairs, On May 18, 1993. He declared that the U.S. would no longer play the game of balancing Iran against Iraq. The strength of the United States and its friends in the region - Egypt, Israel, Turkey and the Gulf Cooperation Council states of Saudi Arabia, Kuwait, Bahrain, Qatar, the United Arab Emirates and Oman - would allow Washington to "counter both the Iraqi and Iranian regimes. "We will not need to depend on one to counter the other" (The-Washington-Institute-for-Near-East-Policy, 1993).

Indyk in his speech also expressed that the Clinton administration's goal in Iraq was to establish clearly that the current regime in Iraq was a criminal and absolute regime and a regime change in Iraq was the ultimate goal of American policy. Although Indyk noted that America's policy was not to force the breakup of Iraq and America's commitment to maintain the territorial integrity of countries, in fact he left little doubt that a regime change was the ultimate goal of American policy (The-Washington-Institute-for-Near-East-Policy, 1993). Other side of Dual Containment was Iran and Martin Indyk indicated that U.S. action toward Iran had no widespread support such as sanctions against Iraq that had the weight of the United Nations resolutions as legitimizing force, so containment of Iran would be more problematic and sanctions against the Islamic Republic of Iran must be multilateral. Indyk's opinion, containment of Iran was different from Iraq. He believed that America must persuade other nations not to engage in military transactions or "normal commercial relations" with Iran.

\section{Factors of supporting Dual Containment Policy}

In the view of the Clinton administration, there was a set of geopolitical situations that enabled the United States to follow the policy of containing both Iran and Iraq without having to build up one against the other in order to balance the two regional powers:

\subsection{End of the Cold War and collapse of the Soviet Union}

The collapse of the Soviet Union led to the United States being raised to the position of the main superpower in the world, so the United States now has a unique and brazen ability to conduct global economic and military policies and the scope of Russian opinion today does not play into Middle East policy decisions to the degree that the Soviet Union did (Martin Indyk, Graham Fuller, Cordesman, \& Marr, 1994). In short, in the view of the Clinton administration, the removal of the Soviet Union from the superpower stage had removed a major strategic consideration from the Persian Gulf policy.

\subsection{Balance of power}

Both Iran and Iraq were weakened by the Iran-Iraq war from 1980 to 1988 by sanctions, military and financial loss of war and in the case of Iraq, by the destructive defeat that the country suffered in the aftermath of its invasion of Kuwait $^{3}$. So, a regional balance of power was established between Iran and Iraq (Gause, 1994). The military weakness of Iran and Iraq after eight years of the Iran-Iraq war reassures Americans of their unilateral containment of Iran and Iraq in the Persian Gulf region.

\subsection{Cooperation of Persian Gulf allies}

After Iraq's invasion of Kuwait, the Persian Gulf Cooperation Council states were more willing to enter into security arrangements with the United States in the region which had some protector and allies among Iraq and also Iran.

\subsection{Positive regional strategic context}

The Arab-Israeli Peace Process has always been the core of U.S. foreign policy in the Middle East, so after the end of the Cold War and the Persian Gulf War, U.S. leaders feel that these developments were able to promote peace between Israel and its Arab neighbors. In this process, Dual Containment policy can play an important role. Because if Iran or Iraq or both continue to oppose an Arab-Israeli Peace Process, these countries are further isolated, thereby strengthening the Dual Containment policy (Martin Indyk et al., 1994).

\footnotetext{
${ }^{3}$ President of Iraq -Saddam Hussein- attacked Kuwait in 1991 after ceasefire in Iran-Iraq war in 1988.
} 


\section{Implementation of the Dual Containment Policy toward Iran}

Compared to Iraq, the strategy of Dual Containment toward Iran was not obvious. In Iran's case, the most important United States motive for the Dual Containment policy included a desire to prevent the export of the Islamic Revolution to the region and to the world. The U.S. containment of Iran was essentially a passive policy that included a mixture of non-intercourse, economic sanctions, and efforts to limit Iranian relations with third countries (Hunter, 2010, p. 50).

Iran in the Persian Gulf was a main power with a gorgeous culture, long and brilliant civilization, and an aggressive relationship with the U.S. From the American point of view, Iran was a revolutionary state that was engaged in outlaw behavior. Martin Indyk believed that:

Iran is paradoxically both a lesser and greater challenge to our policy; lesser in the sense that Iran today does not pose the threat that Iraq did to our interests some five years ago. And our challenge is to prevent Iran five years from now from becoming the kind of threat that Iraq was five years ago (Martin Indyk et al., 1994, p. 5).

The main reasons of conflict between the American government (Clinton's administration) regarding the Islamic Republic of Iran in the Persian Gulf region in the view point of Martin Indyk were: first, support of terrorism throughout the world; second, Iran's attempts to acquire nuclear Weapons of Mass Destruction; third, Iran was acquiring offensive capabilities in the Persian Gulf region that would threaten the GCC states and promote instability among US allies in the Persian Gulf area; fourth, the opposition of the Iranian regime to the Arab-Israeli Peace Process and finally Iran's record of human rights abuses.

On May 6, 1995, President Clinton signed an executive order strengthening the policy of Dual Containment toward Iran. According to this executive order there were imposed some bans on Iran like arms ban, dual use technologies ban, import ban on Iranian products coming into the United States, controls on certain items for export to Iran, and a diplomatic position of blocking all lending to Iran from international financial institutions (Laipson, Sick, \& Cottam, 1995). In sum the main purpose of the dual containment policy was to block the transfer of dangerous goods and technologies to Iran and to pressure Iran's economy by limiting its financial ability to acquire critical materials and fund undesirable overseas activities.

There are some important reasons for the dual containment or Clinton strategy: 1- Clinton administration was afraid of rising terrorist activities against the Middle East peace process that inevitably Iran was at the axis of the charges. 2- There were seen Signs of Iran's efforts to achieve nuclear weapons of mass destruction. 3- United States allies had the expectation that there must not be contradiction between the real policy and current deeds of Clinton's administration.

\section{Implementation of the Dual Containment Policy toward Iraq}

Some internal and external factors caused Iraqi regime an outlaw state in the international community. Internal factors were such as Brutal repression of Kurds in the north, the Shiites in the south and use of chemical weapons in Kurd city of Halabche ${ }^{4}$ in Iraq. External factors were such as use of biological and chemical weapons in his war with Iran, Iraqi invasion to kingdom of Kuwait. However, the UN resolutions and sanctions against Iraq gave this feeling to the Clinton administration that the sanctions are having some effects on Iraqi regime, as Iraq accepted the resolution no.715 of the Security Council that allowed monitoring of its WMD programs for a long time.

U.S. containment of Iraq by contrast of Iran, was different and more active. The Iraqi containments were including United Nations sanctions imposition of no-fly zones over the northern and southern parts of Iraq, also various kinds of sanctions opposed to minimize the relative suffering of the Iraqi people, and attack on targets in Iraq by United States when Iraq violated the no-fly zones. The U.S. invasion of Iraq by the administration of President George H. W. Bush in March 2003 was a direct consequence of the U.S. policy of Dual Containment that was formalized in the administration of President Clinton and was adopted informally in the administration of President George W. Bush. But under President George W. Bush, containment went from passive aggressive to active-aggressive and also this transition in the United States policy was to Iraq and not to Iran (Hunter, 2010).

Some of the Arab conservative member states of the Persian Gulf also had opposing view point regarding to the U.S. containment policy against Iraqi regime. For example Sean Foley in Journal of "Middle East Review of International Affairs" in 1999 states: "In recent years, however, U.S.-UAE relations have deteriorated because the UAE objects to Washington's policy of containing Iraq and supporting Israel" (Foley, 1999, p. 33). The UAE sheikhdom officials argued that Iraq has "fulfilled most of its obligations to the international community" and that a "militarily strong and united Iraq is needed to balance Iranian power" (Al-Shayeji, 1997). Ruler of the UAE sheikh Zaid believed that Baghdad does not threaten its neighbors, and has referred to the Iraqi sanctions regime as unjust and during the GCC's conference on December 1997, pushed for breaking sanctions over Iraq with the United States (Gardner, 1998).

Madeleine K. Albright, US secretary of states in December 1998 declared the new stage of Dual Containment against Iraq and said the Washington policy of Dual Containment regarding Iraq had changed to one of "containment Plus regime change" (Priest \& schneider,

\footnotetext{
4 Halabche is a Kurd city in Iraq near Iranian boarders that was bombarded with chemical weapons by Iraqi regime during the Iran-Iraq war.
} 
1999).

Evaluation of the "Dual Containment Policy"

The main question is Was U.S. foreign policy - Clinton's administration policy - of containing Iran effective and well-matched with US long-term interests in the Persian Gulf region the same as ending terrorism, establishing a stable democracy in Iraq, and securing oil interests for the long time? To evaluate the effectiveness of US containment of Iran with US long-term interests in mind, it is better to look at some scholars' view points about containment policy against Iran and Iraq. Litwak (2002) argues that "rogue state" policy had pushed US policymakers toward a generic strategy of containment and isolation that allowed for little flexibility in dealing with Iran and Iraq. Litwak further argues that rogue state policy had such significantly deep effects on US foreign policy that even after Khatami ${ }^{5}$ (Iran's reformist president and proponent of East-West dialogue) was elected president, the U.S. was unable to adapt to this development in Iranian politics. "There was formidable opposition in the Republican-led Congress and beyond to any change from a comprehensive containment policy toward Iran. By demonizing and lumping these states as an instrument of political mobilization, the rogue state policy obscured understanding of these countries and distorted policy-making" (Litwak, 2002).

Zibigniew Brzezinski ${ }^{6}$ and Brent Sowcroft ${ }^{7}$ (1997) believed Clinton teams' initial Middle East policy had two aspects: continued support for the peace process and dual containment of Iraq and Iran. The Clinton administration had little opportunity to oust Saddam except at great cost in blood and treasure. In other side, U.S. sanctions against Iran, although doing some damage to the Iranian economy, have produced no major achievements and increasingly isolate America rather than their target. They criticized the Clinton policy that it could not overthrow Saddam Hussein from power and also couldn't isolate Iran:
"... Dual containment" had become "more slogan than a strategy. However, and the policy may not be sustainable for much longer. In trying to isolate both of the Gulf s regional powers, the policy lacks strategic viability and carries a high financial and diplomatic cost. Saddam Hussein is still in power six years after his defeat at the hands of a multinational coalition and the international consensus on continuing the containment of Iraq is fraying. The strident U.S. campaign to isolate Iran, in turn, drives Iran and Russia together and the United States and its Group of Seven allies apart"(Brzezinski, Scowcroft, \& Murphy, 1997).

Brzezinski and Scowcroft (1997) concluded that however

\footnotetext{
${ }^{5}$ Mohammad Khatami was the fifth reformist President of Iran from 1997 to 2005 that his basic doctrine was "dialogue of civilizations".

${ }_{7}^{6}$ Former National Security Advisor under President Carter administration.

Former National Security Advisor under George H.W. Bush administration.
}

one judges its achievements to date, dual containment cannot provide a sustainable basis for U.S. policy in the Persian Gulf.

As an analysis to above mentioned critical sentences it should be said that the dual containment policy regarding Iran and Iraq both could not reach to its goal. Because after Iran Iraq war immediately Iraq attacked Kuwait in 1990 and captured Kuwait city and on the other side it couldn't stop Iran from its ambitions in the region and world and following the policy of achieving nuclear energy.

McCallen and Mraz, two scholars of the American Naval Postgraduate School argue that dual containment was "nothing more than a lack of policy. If the United States truly wants to influence these regimes (Iran and Iraq) the approach should be changed to open dialogue and constructive."(J. Mraz \& McCallen, 1996). They believed that the only effect of the dual containment policy on Iran has been economic, and sanctions caused opening new and larger markets with Europe, Japan and Russia for Iran and US containment shifted the blame from the Iranian government's failing economic policies onto the United States. It seems during presidency of Mohammad Khatami it was a good opportunity for U.S. to make a good relationship with Iranian government for the first time after the Islamic revolution in 1979, but the policy of containing and isolating Iran during the period of dual containment policy was as a barrier against any direct dialogue between Iran and U.S.

Another point of view believes that the "end of the Cold War has reduced the strategic significance of the Persian Gulf region" and after the Cold War "there is considerable disagreement about the nature and importance of the remaining American interests there" (Conry, 1994, p. 1). Conry believes goals such as 1) maintaining access to the Persian Gulf fossil reserves at a reasonable price, 2) preventing nuclear proliferation in the region, and 3) maintenance or creating regional stability that some of proponents of an activist US role in the Persian Gulf such as Edward B. Atkeson, Anthony Lake and James A. Phillips argue, none of them is vital to American national security (Conry, p. 1).

Firstly, according to Anthony Lake, oil was as one of America's vital interests in the region: "Despite the end of the superpower rivalry, the Middle East remains of vital interest to the United States," (Lake, 1994b), but Conry argues that access to the Persian gulf petroleum is not so fundamental to the American economy that it rises to the level of a vital interest because during the Cold War, control of Persian Gulf's fossil reserves by the Soviet Union would have enabled Moscow to threaten Washington's European allies, which get most of their oil from the Middle East. But as political scientist, Richard K. Hermann has pointed out, after the collapse of the Soviet Union; the same danger could not arise from any potential hegemony. On other hand, the regional countries of the Persian Gulf are deeply dependent on oil for developing their projects and funding their military purchases, so the regional member states can only threaten to increase the price of oil. However, the options for 
petroleum alternatives and other energies and the dependence of most regional economies on the advanced industrial economies limit the range of changes. On the other hand, even if a regional member state were going to increase the crude oil prices, that would have a relatively minor impact on the American economy, because in a worst-case scenario the ultimate cost to the American economy would have been a loss of 1 percent of real gross domestic product (Henderson, 1991, pp. 41-45), while the yearly U.S. military spending in the defense of the Persian Gulf region, in peacetime, was around USD50 billion. (Ravenal, 1991).

Secondly, there is the vital US interest in the Middle East the prevention of proliferation of nuclear weapons. Barbara Conry believes (Conry, p. 2):

Experience has demonstrated that there is relatively little the international community can do to deter regimes that are intent on becoming nuclear powers. Israel, India, and Pakistan all acquired nuclear capabilities during the Cold War, against the will of the international community.

So she concluded that Washington should adjust to that new reality that even if Iran and Iraq were to develop nuclear arsenals, they would not necessarily represent a threat to the security of the United States and possession of nuclear weapons does not in itself award a vital military or diplomatic advantage. For example, Israel's status as the sole nuclear power in the Middle East region, has never afforded it a measurable advantage in dealing with its non-nuclear Arab enemies (Fein, July 13, 1994). So failure to prevent nuclear proliferation in the region, does not necessarily pose a mortal threat to U.S. security because a nuclear-free Persian Gulf is a peripheral, rather than a vital, American interest.

Thirdly, a third vital U.S. interest in the Persian Gulf is regional stability and Barbara Conry maintains that:

The Middle East has never been a stable region, and there is scant reason to believe that the prospects for stability there have improved". Then she concludes that: "there is no reason to think that instability in the post-Cold War era somehow suddenly represents a threat to American security...As long as Middle Eastern players do not seek regional stability, there is little the United States can do to advance it. Indeed, stability in the Persian Gulf region is so chimerical an objective that it could not even be called a legitimate peripheral interest, much less a vital U.S. interest (Conry, p. 2).

Finally Conry concludes that when there is any vital national security interest in the Persian Gulf region, also there is no justification for undertaking the policy of dual containment by the President Clinton administration, and legitimate peripheral interests of the United States do not merit allowing it to be drawn into regional turmoil or another Persian Gulf War.

According to the claim by US policy makers, one of the most important aspects of the dual containment policy was deterring the Islamic Republic of Iran from supporting terrorism and terrorist groups such as the Hizbollah ${ }^{8}$ and Al-Qaedah, but according to the US annual state department report, the dual containment policy had seen little success in deterring Iraq or Iran's support for international terrorism ("Country Reports on Terrorism: 2005," released April 2006). These reports indicate that Iran, to oppose the Arab-Israeli Peace Process in the Middle East provides material support to the terrorist groups such as Hizbollah, Hamas, Palestinian Islamic Jihad, etc. Although recently in 2004 the new Iraqi government was removed from the terrorism list, Iran still is in the American black list of those supporting terrorism.

Some American scholars confirm Kennan's remarks about the former Soviet Union:

America's contest with the Soviet Union, it
was inappropriate for the United States to
seek the Soviets' total defeat... so Moscow
had space and thus it made sense to
concentrate on Russia's periphery. Those
areas which were vital to U.S.
interest-those, and only those, should be
defended (Pelletiere, 1999, p. 17).

The U.S. should adopt a similar strategy with regard to the northern Persian Gulf region states of Iran and Iraq because the U.S. does not need the oil of both Iran and Iraq when it has access to the oil fields of the southern Arab states of the Persian Gulf.

From another perspective, also some Persian Gulf coastal states did not believe that the dual containment policy was effective on Iran. For example, Omani's King Sultan Qaboos' reaction to the US policy of dual containment was that "Iran is the largest country in the [Persian] Gulf with 65 million people. You cannot isolate it" (Miller, 1997, p. 14).

Stability and security of the Persian Gulf region always has been the fundamental objective of American foreign policy. As the former Secretary of State "William Perry" stated, "Nowhere in the world does the United States more clearly have vital interests at stake than in the Persian Gulf" (Perry, 1995, p. 8). In this regard, the Clinton administration adopted the Dual Containment Policy with different objectives for Iraq and Iran. At the first step, the common idea about Iraq and Iran was that: "The regimes of both countries are viewed as dangerous because their policies are hostile to American interests" (Indyk, 1993, p. 2). At the second step there was a different policy regarding Iran and Iraq: The Clinton administration's Dual Containment Policy objectives regarding Iran were: 1) to persuade Tehran to change its outlaw behavior by isolation it; 2) to halt efforts of Tehran's pursuit of weapons of mass destruction and its nuclear ambitions; 3) to prevent Iran's links with terrorism; 4) to end Iran's violent opposition to the Arab- Israeli Peace Process; 5) to curb Tehran's threats against neighboring states; 6) to constrain Iran to comply with human rights (Wright \& Broder, August 11, 1993). In January 1989,

\footnotetext{
${ }^{8}$ Hezbollah is a semi military group in Lebanon that is supported by Iran and had attacked Israeli regime many times.
} 
President Bush (elder) had referred to Iran in his initial address saying: “... good will begets good will. Good faith can be a spiral that endlessly moves on ..." (Gary Sick, p. 66). However, after the Bush administration there was no talk of good will by the Clinton administration and instead U.S. officials developed a special vocabulary in which Iran was characteristically recognized as a "rogue", "terrorist", "outlaw" or "back slash state".

After the end of the Clinton presidency when we analyze the achievement of the above objectives of dual containment regarding the Islamic Republic of Iran, it emerges that the policy of dual containment was not able to achieve any of its claimed goals regarding Iran. According to Martin Indyk, the main sole thinker of dual containment policy: "If we fail in our efforts to modify Iranian behavior, five years from now Iran will be much more capable of posing a real threat to Israel, the Arab world, and Western interests in the Middle East" (Indyk, p. 3). There must be a threat to the Arab coastal states and their western allies, but we see that the Iranian government's relation with the free world even while Mahmud Ahmadinejad, as a hard-liner president, was selected as Iran's president, there was no serious conflict with Iran's neighbors and the western countries. From another point of view, there exist the above-claimed objectives of dual containment regarding Iran even after the end of the period of Clinton's presidency and ending of the dual containment policy. This indicates that the objectives of dual containment policy were not achieved, at least regarding to the Islamic Republic of Iran.

The second axis of dual containment policy was Iraq. Since 1990, the Clinton administration had concluded that Saddam Hussein's regime represents a direct and unacceptable threat to Washington's regional and international interests. Therefore, the U.S. intensified its efforts to contain Iraq by 1) supporting different opposition groups, 2) covert operations to overthrow the Iraqi regime. In this regard, the Clinton administration spent USD \$20 million yearly to achieve its goal (Weiner, 1996, p. 6), but clearly this strategy did not succeed.

Generally, The Clinton administration's Dual Containment Policy objectives regarding Iraq were: 1) to prompt democratic forces to overthrow the Iraqi regime; 2) topple Saddam's regime and replace it with a democratic regime (Wright \& Broder, p. 3); 3) the topple of basic human right by the Saddam Hussein regime of the Iraqi Shiite and the Iraqi Kurds; 4) the challenges that the Iraqi regime posed to the regional security system and to the flow of oil supplies; 5 ) and the attempt to acquire and develop weapons of mass destruction (Bahgat, 1997, p. 59).

As mentioned above, the Clinton administration had different objectives for Iran and Iraq. The common point for both countries was: "the regimes of both countries were viewed as dangerous because their policies were hostile to American interests" (Indyk, p. 2). But the difference was:

... Washington does not advocate the overthrow of the Islamic regime ... [but] administration leaders have espoused a more ambitious agenda for Iraq, [and] [...] they view Saddam as incorrigible [...] the administration does not seek or expect reconciliation with Saddam Hussein's regime (Indyk, p. 2).

So the main objective and desire of the dual containment policy regarding Iraq was the overthrow of the Saddam regime, in essence, regime change. Even though the Iraqi regime of Saddam Hussein was overthrown by the American Forces, it was not as a result of the Dual Containment Policy but rather as the consequence of direct military presence of American forces and its allies against the Iraqi regime after the Clinton presidency and during the George W. Bush (junior) administration. During the Clinton presidency, Washington only relied on unsuccessful sanctions to overthrow the Iraqi regime.

\section{Conclusion}

In general, since the victory of the Islamic Revolution in Iran in 1979, there were some policies to contain the export of Iran's revolution and ideologies as an aggression to the Arab conservative neighbors and also preservation of interests of other countries in the world such as U.S. and western countries from Iranian aggression. A few of these methods of containment are: First, Sanctions (1979-2009) since the Islamic Revolution in Iran in 1979 until the end of the George W. Bush (junior) administration in 2009, many sanctions against Iran were posed but most of them were unilateral with less support from the international community and the United Nations. All in all, US sanctions against Iran failed to overthrow the Iranian regime and could not contain Iran. Additionally, sanctions against Iran caused problems for reformers such as former president Mohammad Khatami to carry out their policies. The collapse of processing the reforms by Mohammad Khatami, led to failure of the reformists and victory for the hardliners in the next round of elections in 2005 in the hope of economic reforms by the new president (Ahmadinejad) who promised economic reforms.

Second, UN Sanctions (Present): Jeffrey Schott, a member of the "Peterson Institute" who drafted the early sanctions of the U.S. against Iran in the 1980's argues that the UN sanctions would not stop Iran from building a nuclear weapon and at best, sanctions would only postpone for a few years the Iranian desire to have nuclear weapons (Schott, 2006). Schott also believes that the UN sanctions against Iraq's WMD program were not successful because international support for sanctions against Iraq was simultaneous with the low oil prices of the 1990s. Even though the U.S. put pressure on its allies not to do business with Iran, need of western countries for Iran's oil, created a dilemma for these countries.

Third: Use of non-state actors: After the Vietnam War and also during the Cold War, the U.S. did not want to use its military forces directly to contain the Soviet Union, so 
policymakers in Washington decided to support their allies, most of whom were far from liberal and democratic parameters and it was risky to long-term U.S. interests, especially in the Middle East and the Persian Gulf region.

\section{REFERENCES}

[1] Sick, G. (2002). Iran's foreign policy: A revolution in transition. In N. R. Keddie \& R. Matthee (Eds.), Iran and the surrounding world: interactions in culture and cultural politics Washington: University of Washington Press.

[2] Alikhani, H. (2000). Sanctioning Iran: Anatomy of a failed policy London: I. B. Tauris.

[3] Lake, A. (1994a). Confronting Backlash States, Foreign Affairs, 73(2), 45.

[4] The-Washington-Institute-for-Near-East-Policy. Clinton Administration Policy Toward the Middle East. Policy Watch(Special Report), 56.

[5] Martin Indyk, Graham Fuller, Cordesman, A., \& Marr, P. (1994). Symposium on Dual Containment: U.S. Policy Toward Iran and Iraq,". Middle East Policy, 3(1).

[6] Hunter, R. E. (2010). Building Security in the Persian Gulf. Santa Monica: The RAND Corporation.
[7] Gardner, J. (1998, 23 February 1998). Kofi Annan Clinches UN Peace Deal with Saddam. Financial Times,

[8] Priest, D., \& schneider, H. (1999, 7 March 1999). Over Iraq, self -defense Beget war. Washington Post.

[9] Litwak, R. (2002). "Iraq and Iran: From Dual to Differentiated Containment" in Eagle Rules? . New Jersey: Pearson Education, Inc.

[10] Brzezinski, Z., Scowcroft, B., \& Murphy, R. (1997). Differentiated containment. Foreign Aff., 76, 20.

[11] Conry, B. (1994). America's Misguided Policy of Dual Containment [Electronic Version]. Cato Foreign Policy Briefing. Retrieved November 10, 1994,

[12] Ravenal, E. C. (1991). Designing Defense for a New World Order: The Military Budget in 1992 and Beyond. Washington: Cato Institute.

[13] Pelletiere, S. (1999). Landpower and dual containment: rethinking America's policy in the [Persian] Gulf Retrieved. from Strategic Studies Institute.

[14] Miller, J. (1997). Creating Modern Oman: An Interview with Sultan Qaboos. foregion affairs, 76(3).

[15] Weiner, T. (1996, 7 September 1996). Iraqi Offensive Into Kurdish Zone Disrupts US Plot To Oust Hussein. New York Times,

[16] Bagat, G. (1999). Security in the Gulf: The View from Oman. Security Dialogue, 30(4), 445-458. 